\title{
Esensi dan Sinkronisasi Pengaturan Mengenai Persetujuan Presiden dalam Proses Pidana Anggota DPR, Hakim Agung, Hakim Konstitusi, dan Anggota BPK
}

\author{
Essence and Synchronization of Regulations on Presidential Approval in \\ Criminal Processes to The Members of The House of Representatives, Judges \\ of The Supreme Court and The Constitutional Court, and Members of The Audit Board of \\ The Republic of Indonesia
}

\author{
Novianto M. Hantoro \\ Pusat Penelitian Badan Keahlian DPR RI \\ Komplek MPR/DPR/DPD Gedung Nusantara I Lantai 2, \\ Jl. Jenderal Gatot Subroto Jakarta \\ Email:nmhantoro@yahoo.com \\ Naskah diterima: 7 Agustus 2018 \\ Naskah direvisi: 17 September 2018 \\ Naskah diterbitkan: 1 November 2018
}

\begin{abstract}
The laws governing the House of Representatives, the Supreme Court, the Constitutional Court, and the Supreme Audit Board, each require the need for presidential approval in criminal proceedings against state officials in that institution. The public spotlight is more often directed at politicians by looking at the petition for judicial review submitted, even though the provision also applies to supreme judges, constitutional judges, and members of the Supreme Audit Board. The problem to be studied in this paper is what is the essence of the president's approval in the criminal process of members of the House of Representatives, supreme judge, constitutional judge, and members of the Supreme Audit Agency, as well as how to synchronize these arrangements. The essence of the president's approval was reviewed based on the opinion of the Constitutional Court stated in its decision, the history of the regulation in the law, and the reference to the norm in the 1945 Constitution of the Republic of Indonesia. Based on the results of the study, it is difficult to obtain certainty of the essence of the approval of the president, except in the context of maintaining the continuity of the wheels of government which is not appropriate if it is then carried out by giving authority to the president to give approval in criminal proceedings. The results of the study also found six points of synchronization problems. Based on the results of the study, three options are recommended, namely removing these provisions and looking for the options to establishing a forum previligiatum; regulate in separate laws, or be included as part of criminal procedural law.
\end{abstract}

Keywords: synchronization, state officials, presidential approval, criminal proceedings.

\begin{abstract}
Abstrak
Undang-undang yang mengatur Dewan Perwakilan Rakyat, Mahkamah Agung, Mahkamah Konstitusi, dan Badan Pemeriksa Keuangan, masing-masing mensyaratkan perlunya persetujuan presiden dalam proses pidana terhadap pejabat negara yang berada di lembaga tersebut. Sorotan masyarakat lebih sering ditujukan kepada politisi. Hal ini terlihat dari permohonan uji materi yang diajukan, padahal ketentuan tersebut juga berlaku untuk hakim agung, hakim konstitusi, dan anggota Badan Pemeriksa Keuangan. Permasalahan yang ingin dikaji dalam tulisan ini adalah apa esensi persetujuan presiden dalam proses pidana anggota Dewan Perwakilan Rakyat, hakim agung, hakim konstitusi, dan anggota Badan Pemeriksa Keuangan, serta bagaimana sinkronisasi pengaturan tersebut. Esensi persetujuan presiden dikaji berdasarkan pendapat Mahkamah Konstitusi yang tertuang dalam pertimbangan putusannya, sejarah pengaturan dalam undangundang, dan rujukan norma tersebut di Undang Undang Dasar Negara Republik Indonesia Tahun
\end{abstract}


1945. Sinkronisasi pengaturan dilihat berdasarkan peristilahan, tindak pidana yang dikecualikan, dan pelaku penegakan hukum pidana. Berdasarkan hasil kajian, sulit mendapatkan kepastian esensi dari persetujuan presiden, kecuali dalam konteks untuk menjaga keberlangsungan roda pemerintahan yang itu pun tidak tepat apabila kemudian dilakukan dengan memberikan kewenangan kepada presiden untuk memberikan persetujuan dalam proses pidana. Hasil kajian juga menemukan adanya 6 (enam) ketidaksinkronan pengaturan mengenai persetujuan presiden tersebut. Berdasarkan hasil kajian tersebut direkomendasikan 3 (tiga) opsi, yaitu menghapus ketentuan persetujuan presiden tersebut dan mengkaji kemungkinan pembentukan forum previligiatum; mengatur dalam undangundang tersendiri, atau dimasukkan sebagai bagian dari undang-undang hukum acara pidana.

Kata kunci: sinkronisasi, pejabat, persetujuan presiden, proses pidana

\section{Pendahuluan}

Beberapa undang-undang memberlakukan ketentuan khusus terkait dengan proses pidana terhadap pejabat-pejabat tertentu. Ketentuan khusus yang dimaksud adalah perlunya tindakan administrasi berupa persetujuan presiden dan/ atau perintah jaksa agung. Sementara yang dimaksud dengan proses pidana adalah tahapan kegiatan atau cara kerja yang dilakukan aparat penegak hukum untuk menangani perkara pidana, di antaranya penyelidikan, penyidikan, dan penuntutan. ${ }^{1}$ Beberapa undang-undang yang dimaksud, antara lain:

1. Undang-Undang Nomor 14 Tahun 1985 tentang Mahkamah Agung sebagaimana telah diubah terakhir dengan Undang-

\footnotetext{
Pengertian ini diolah dari definisi yang diberikan oleh Zainul Bahri tentang proses peradilan pidana, yaitu runtutan atau rentetan yang menunjukkan mekanisme atau cara kerja untuk mencari dan mendapatkan suatu pembenaran dalam suatu perkara pidana. Zainul Bahri, Kamus Hukum, Bandung; Angkasa, 1994, hal. 43.
}

Undang Nomor 3 Tahun 2009 (selanjutnya disebut UU MA);

2. Undang-Undang Nomor 24 Tahun 2003 tentang Mahkamah Konstitusi sebagaimana telah diubah terakhir dengan Undangundang Nomor 4 Tahun 2014 (selanjutnya disebut UU MK);

3. Undang-Undang Nomor 17 Tahun 2014 tentang Majelis Permusyawaratan Rakyat, Dewan Perwakilan Rakyat, Dewan Perwakilan daerah, dan Dewan Perwakilan Rakyat Daerah sebagaimana telah diubah terakhir dengan Undang-Undang Nomor 2 Tahun 2018 (selanjutnya disebut UU MD3);

4. Undang-Undang Nomor 15 Tahun 2006 tentang Badan Pemeriksa Keuangan (selanjutnya disebut UU BPK);

5. Undang-Undang Nomor 23 Tahun 1999 tentang Bank Indonesia (selanjutnya disebut UU BI);

6. Undang-Undang Nomor 22 Tahun 2004 tentang Komisi Yudisial sebagaimana telah diubah dengan Undang-Undang Nomor 18 Tahun 2011 (selanjutnya disebut UU KY);

7. Undang-Undang Nomor 16 Tahun 2004 tentang Kejaksaan Republik Indonesia (selanjutnya disebut UU Kejaksaan RI;

8. Undang-Undang Nomor 32 Tahun 2004 tentang Pemerintahan Daerah yang kemudian digantikan dengan UndangUndang Nomor 23 Tahun 2014 (selanjutnya disebut UU Pemda).

Pejabat-pejabat di dalam undang-undang tersebut, meskipun sering disebut sebagai pejabat negara, namun tidak semua dapat disederajatkan. Klasifikasi jabatan tidak dapat dipisahkan dengan klasifikasi lembaganya. Jimly Asshiddiqie menyebutkan ada 7 lembaga tinggi negara, yaitu (presiden), Majelis Permusyawaratan Rakyat (MPR), Dewan Perwakilan Rakyat (DPR), Dewan Perwakilan Daerah (DPD), Mahkamah Agung (MA), Mahkamah Konstitusi (MK), dan Badan Pemeriksa Keuangan (BPK). ${ }^{2}$ Dengan demikian,

Klasifikasi ini merujuk pada Jimly Asshiddiqie yang tidak memasukkan KomisiYudisialsebagailembagatingginegara, 
presiden, anggota MPR, anggota DPR, anggota DPD, hakim agung, hakim konstitusi, dan anggota BPK adalah pejabat negara utama.

Jaksa agung, Komisioner Komisi Yudisial, Gubernur, Deputi Gubernur Senior, dan Deputi Gubernur Bank Indonesia merupakan pejabat negara pusat di bawah pejabat negara utama. Kepala daerah provinsi dan anggota DPRD provinsi, serta kepala daerah kabupaten/kota dan anggota DPRD kabupaten/kota merupakan pejabat daerah. ${ }^{3}$ Tulisan ini akan membatasi hanya pada pejabat negara utama.

Sorotan terhadap perlunya persetujuan presiden dalam proses pidana lebih banyak ditujukan kepada politisi dan kepala daerah. Hal tersebut ditunjukkan dengan pengajuan permohonan uji materi terhadap UU Pemda dan UU MD3 di MK. Permohonan pengujian terhadap UU KY juga pernah diajukan (MK dalam amar putusannya tidak menerima permohonan tersebut), namun tidak ada permohonan uji materi terhadap UU MK dan UU BPK.

MK telah mengeluarkan putusan terhadap perkara-perkara mengenai persetujuan presiden melalui Putusan Nomor 73/PUU-IX/2011 dalam perkara pengujian Undang-Undang Nomor 32 Tahun 2004 tentang Pemerintahan Daerah sebagaimana telah diubah terakhir dengan Undang-Undang Nomor 12 Tahun 2008 tentang Perubahan Kedua Atas UndangUndang Nomor 32 Tahun 2004 tentang Pemerintahan Daerah (selanjutnya disebut Putusan MKNomor 73/PUU-IX/2011), Putusan Nomor 76/PUU-XII/2014 dalam perkara pengujian Undang-Undang Nomor 17 Tahun

dalam Jimly Asshiddiqie, Perkembangan dan Konsolidasi Lembaga Negara Pasca-Reformasi, Jakarta: Sekretariat Jenderal dan Kepaniteraan Mahkamah Konstitusi, 2006, hal. 42. Penulis menyebutnya sebagai lembaga negara utama dalam Novianto M. Hantoro, "Klasifikasi Jabatan dalam Kelembagaan Negara: Permasalahan Kategori Pejabat Negara”, Jurnal Negara Hukum, Volume 7, Nomor 2, November 2016, hal. 145-166. Klasifikasi lain memasukkan Komisi Yudisial sejajar dengan MA dan MK, salah satunya Patrialis Akbar, Lembaga-Lembaga Negara Menurut UUD NRI Tahun 1945, Jakarta: Sinar Grafika, 2013, hal. 35.

3 Novianto. M. Hantoro, “Klasifikasi....”, hal. 162-163.
2014 tentang Majelis Permusyawaratan Rakyat, Dewan Perwakilan Rakyat, Dewan Perwakilan Daerah, dan Dewan Perwakilan Rakyat Daerah (selanjutnya disebut Putusan MK Nomor 76/ PUU-XII/2014), Putusan Nomor 125/PUU. XIII/2015 dalam perkara pengujian UndangUndang Nomor 22 Tahun 2004 tentang Komisi Yudisial sebagaimana telah diubah dengan Undang-Undang Nomor 18 Tahun 2011 tentang Perubahan Atas Undang-Undang Nomor 22 Tahun 2004 tentang Komisi Yudisial dan Undang-Undang Nomor 14 Tahun 1985 tentang Mahkamah Agung sebagaimana telah diubah terakhir dengan Undang-Undang Nomor 3 Tahun 2009 tentang Perubahan Kedua Atas Undang-Undang Nomor 14 Tahun 1985 tentang Mahkamah Agung (selanjutnya disebut Putusan MK Nomor 125/PUU-XIII/2015), dan Putusan Nomor 16/PUU-XVI/2018 dalam perkara pengujian Undang-Undang Nomor 2 Tahun 2018 tentang Perubahan Kedua Atas Undang-Undang Nomor 17 Tahun 2014 tentang Majelis Permusyawaratan Rakyat, Dewan Perwakilan Rakyat, Dewan Perwakilan Daerah, dan Dewan Perwakilan Rakyat Daerah (selanjutnya disebut Putusan MK Nomor 16/ PUU-XVI/2018).

Putusan MK Nomor 73/PUU-IX/2011 pada intinya memutuskan bahwa tindakan penyidikan yang dilanjutkan dengan penahanan terhadap kepala daerah dan/atau wakil kepala daerah memerlukan persetujuan tertulis dari presiden. ${ }^{4}$ Rumusan putusan ini kemudian dituangkan dalam Undang-Undang Nomor 23 Tahun 2014 tentang Pemerintahan Daerah yang menggantikan Undang-Undang Nomor 32 Tahun 2004.

Uji materi UU MD3 diputuskan dalam Putusan MK Nomor 76/PUU-XII/2014 dan Putusan MK Nomor 16/PUU-XVI/2018.

\footnotetext{
Putusan ini sering diberitakan salah di media massa dengan tafsir tidak perlu lagi adanya persetujuan presiden dalam proses pidana terhadap kepala daerah dan/atau wakil kepala daerah. Hal yang dibatalkan oleh MK adalah tindakan penyelidikan dan penyidikan terhadap kepala daerah dan/atau wakil kepala daerah dilaksanakan setelah adanya persetujuan tertulis dari Presiden atas permintaan penyidik.
} 
Putusan MK yang terbaru menyatakan bahwa pemanggilan dan permintaan keterangan kepada anggota DPR yang diduga melakukan tindak pidana yang tidak sehubungan dengan pelaksanaan tugas sebagaimana dimaksud dalam Pasal 224 UU MD3 (terkait hak imunitas) harus mendapatkan persetujuan tertulis dari presiden. Ketentuan yang dibatalkan oleh MK adalah persetujuan Mahkamah Kehormatan Dewan dan tambahan frasa pertimbangan Mahkamah Kehormatan Dewan.

Berdasarkan existing law (hukum yang berlaku yang tidak terbatas pada undangundang melainkan juga putusan pengadilan), masih ada ketentuan mengenai persetujuan presiden dalam proses pidana untuk pejabat negara utama. Pejabat negara utama tersebut hanya dibatasi pada anggota DPR, hakim agung, hakim konstitusi, dan anggota BPK karena untuk presiden diatur dalam UUD 1945 melalui mekanisme pemakzulan (impeachment), sementara untuk anggota MPR dan anggota DPD tidak diatur dalam UU MD3 saat ini. Permasalahan yang ingin dikaji dalam tulisan ini:

1. Apa esensi persetujuan presiden dalam proses pidana terhadap anggota $\mathrm{DPR}$, hakim agung, hakim konstitusi, dan anggota BPK?

2. Bagaimana sinkronisasi pengaturan mengenai persetujuan presiden dalam proses pidana terhadap pejabat-pejabat tersebut?

Dika Yudanto dan Nourma Dewi menulis tentang Sinkronisasi Undang-Undang Administrasi Pemerintahan dengan Undang-Undang Tindak Pidana Korupsi dalam Penyelesaian Kasus Penyalahgunaan Wewenang Pejabat Pemerintah di Indonesia. Meskipun terkait dengan sinkronisasi undang-undang dan pejabat pemerintah, namun tulisan ini membahas mengenai penyalahgunaan wewenang yang merupakan salah satu unsur dalam Pasal 3 Undang-Undang Pemberantasan Tindak Pidana Korupsi, yang menurut Undangundang Nomor 30 Tahun 2014 tentang Administrasi Pemerintahan harus dinyatakan terlebih dahulu kebenarannya melalui Pengadilan Tata Usaha Negara. Hal ini berpotensi membuat penyalahgunaan wewenang pejabat pemerintah berada di dua rezim hukum yang berbeda. Permasalahan yang dikaji dalam tulisan tersebut adalah bagaimana sinkronisasi Undang-Undang Administrasi Pemerintahan dengan UndangUndang Pemberantasan Tindak Pidana Korupsi dalam menyelesaikan penyalahgunaan wewenang pada pejabat di Indonesia dan penyelesaian pejabat pemerintah yang terbukti menyalahgunakan wewenang dan mengakibatkan kerugian negara. Pasal 21 ayat (2) Undang-Undang Administrasi Pemerintahan menyatakan badan dan/atau pejabat pemerintahan dapat mengajukan permohonan kepada pengadilan untuk menilai ada atau tidak ada unsur penyalahgunaan wewenang dalam keputusan, jika dikaitkan dengan Pasal 3 Undang-Undang Pemberantasan Tindak Pidana Korupsi mengenai unsur penyalahgunaan wewenang maka harus diujikan terlebih dahulu kebenarannya di Pengadilan Tata Usaha Negara. ${ }^{5}$

Tri Mulyani menulis tesis mengenai Izin Presiden untuk Melakukan Pemeriksaan Kepala Daerah yang Diduga Melakukan Tindak Pidana Korupsi (Kajian dalam Perspektif Equality before the Law). Tulisan ini merupakan studi terhadap ketentuan Pasal 36 ayat (1) Undang-Undang Nomor 32 Tahun 2004 tentang Pemerintahan Daerah yang mengatur mengenai izin presiden untuk melakukan pemeriksaan kepala daerah yang diduga melakukan tindak pidana korupsi dihadapkan dengan prinsip equality before the law dalam Pasal 27 ayat (1) UUD 1945. Secara singkat, penelitian ini menyimpulkan bahwa izin presiden untuk melakukan pemeriksaan kepala daerah yang diduga melakukan tindak pidana korupsi bertentangan dengan konsep equality before the law. ${ }^{6}$

Try Sarmedi Saragih menulis tentang Kewenangan Penyidik dalam Memanggil dan Memeriksa Anggota Dewan Perwakilan Rakyat

Dika Yudanto dan Nourma Dewi "Sinkronisasi UndangUndang Administrasi Pemerintahan dengan UndangUndang Tindak Pidana Korupsi dalam Penyelesaian Kasus Penyalahgunaan Wewenang Pejabat Pemerintah di Indonesia", Jurnal Serambi Hukum, Vol. 10, No. 02, Agustus 2016-Januari 2017, hal. 32-45.

Tri Mulyani, "Izin Presiden untuk Melakukan Pemeriksaan terhadap Kepala Daerah yang Diduga Melakukan Tindak Pidana Korupsi”, Tesis, Program Pasca-Sarjana Universitas Kristen Satya Wacana, Salatiga, 2010. 
yang Diduga Melakukan Tindak Pidana. Artikel ini difokuskan pada permasalahan pemanggilan dan pemeriksaan oleh penyidik kepolisian terhadap anggota DPR yang diduga melakukan tindak pidana harus seizin presiden dan hal tersebut bertentangan dengan asas equality before the law. Hasil penelitian ini menyimpulkan bahwa proses penyidikan terhadap anggota DPR yang diduga melakukan tindak pidana harus seizin presiden berdasarkan Pasal 245 ayat (1) Undang-Undang Nomor 17 Tahun 2014 tentang MPR, DPR, DPD, dan DPRD untuk menjaga harkat dan martabat anggota DPR agar tidak diperlakukan sembrono dan sewenang-wenang. Proses pemanggilan dan pemeriksaan yang cukup panjang oleh penyidik kepolisian akan memengaruhi hasil dari penyidikan tersebut. Izin presiden akan mengganggu dan menghambat kinerja penyidik kepolisian untuk melakukan proses penegakan hukum. Terhambatnya proses penyidikan dalam penegakan hukum tidak sesuai dengan prinsip due process of law. Perlu dibuat mekanisme pemisahan kewenangan anggota DPR sebagai pejabat negara dan sebagai subjek hukum agar proses penegakan hukum sesuai dengan asas bersifat cepat, sederhana, dan berbiaya ringan dan prinsip-prinsip negara hukum yang menjunjung tinggi persamaan, perlakuan, kepastian dan keadilan. ${ }^{?}$

Penelitian yang dilakukan Tri Mulyani dan Try Sarmedi Saragih menyimpulkan bahwa izin presiden bertentangan dengan asas persamaan kedudukan dalam hukum (equality before the law) dan akan menghambat kinerja penyidik kepolisian untuk melakukan proses penegakan hukum. Fokus penelitian juga hanya ditujukan pada politisi (anggota DPR dan DPRD) dan kepala daerah. Fokus kajian ini berbeda karena akan menganalisis ketentuan mengenai persetujuan presiden yang berlaku juga pada pejabat negara utama yang lain sebagaimana diatur di beberapa undang-undang yang telah

Try Sarmedi Saragih, "Kewenangan Penyidik dalam Memanggil dan Memeriksa Anggota Dewan Perwakilan Rakyat yang Diduga Melakukan Tindak Pidana”, diakses secara online dari http://e-journal.uajy.ac.id/11226/1/ JURNAL.pdf, pada 1 Agustus 2018. disebutkan sebelumnya, di antaranya UU MA, UU MK, dan UU BPK.

Penelitian Dika Yudanto dan Nourma Dewi mengkaji mengenai sinkronisasi UndangUndang Administrasi Pemerintahan dengan Undang-Undang Pemberantasan Tindak Pidana Korupsi dalam penyelesaian kasus penyalahgunaan wewenang pejabat pemerintah di Indonesia. Sinkronisasi dalam penelitian tersebut berkaitan dengan penyelesaian perkara penyalahgunaan wewenang oleh pejabat berdasarkan Undang-Undang Administrasi Negara dan Undang-Undang Pemberantasan Tindak Pidana Korupsi. Kajian di dalam tulisan ini, meskipun membahas hal yang sama mengenai sinkronisasi, namun sinkronisasi dalam tulisan ini berkaitan dengan pengaturan mengenai persetujuan presiden.

Kajian terhadap adanya persetujuan presiden dalam proses pidana pejabat negara utama dalam proses penegakan hukum pidana dapat ditinjau dari berbagai sudut pandang. Dari sudut pandang hukum administrasi negara dapat dikaji mengenai izin atau persetujuan tertulis presiden. Dari sudut pandang filsafat hukum dapat dikaji mengenai equality before the law. Dari sudut pandang hukum pidana dapat dikaji mengenai hukum acara atau proses peradilan pidana. Tulisan ini akan mengkaji dari sudut pandang hukum administrasi negara mengenai esensi persetujuan presiden dalam proses pidana terhadap anggota DPR, hakim agung, hakim konstitusi, dan anggota BPK, serta dari sudut pandang hukum tata negara, khususnya ilmu perundang-undangan mengenai sinkronisasi pengaturan dan persetujuan presiden dalam proses pidana terhadap pejabatpejabat tersebut.

Tujuan penulisan ini untuk mengetahui esensi persetujuan presiden dalam proses pidana terhadap anggota DPR, hakim agung, hakim konstitusi, dan anggota BPK dan sinkronisasi pengaturan mengenai persetujuan presiden dalam proses pidana terhadap pejabat-pejabat tersebut. Dari hasil kajian ini diharapkan dapat memperbaiki undang-undang yang berlaku saat ini. 


\section{Esensi Kewenangan Presiden Memberikan Persetujuan dalam Proses Pidana}

Esensi dari kewenangan presiden memberikan persetujuan dalam proses pidana terhadap pejabatpejabat tertentu akan dikaji berdasarkan pendapat MK dan sejarah pengaturannya. Selain itu, akan dikaji pula sumber kewenangan presiden yang diberikan oleh undang-undang tersebut diturunkan dari kekuasaan presiden yang mana dalam UndangUndang Dasar Negara Republik Indonesia Tahun 1945 (UUD 1945).

Pertimbangan MK dalam Putusan Nomor 73/PUU-IX/2011, antara lain menyebutkan:

"Oleh karena itu persetujuan tertulis dari Presiden tidak boleh menjadi hambatan bagi proses penyelidikan dan penyidikan kepala daerah yang bersangkutan, karena esensi dari persetujuan tertulis Presiden hanyalah agar Presiden sebagai pimpinan dari para kepala daerah mengetahui bahwa pimpinan dari suatu daerah akan mengalami proses hukum yang membatasi ruang geraknya, sehingga yang bersangkutan tidak dapat menjalankan tugas pemerintahan dengan baik dan akan berakibat pada terjadinya kekosongan pimpinan daerah. Berdasarkan hal itu Presiden melahi Menteri Dalam Negeri segera dapat mengambil langkah-langkah sesuai dengan peraturan perundang-undangan yang berlaku".

Pendapat MK dalam Putusan Nomor 76/PUUXII/2014 dan 16/PUU-XVI/2018 menyebutkan:

"Pelaksanaan fungsi dan hak konstitusional anggota DPR tersebut juga harus diimbangi dengan adanya perlindungan hukum yang memadai dan proporsional, sehingga anggota DPR tidak dengan mudah dan bahkan tidak boleh dikriminalisasi (sic!) pada saat dan/atau dalam rangka melaksanakan fungsi dan kewenangan konstitusionalnya sepanjang dilakukan dengan itikad baik dan penuh tanggung jawab". ${ }^{9}$

Pendapat MK berikutnya:

"Menimbang bahwa salah satu bentuk perlindungan hukum yang memadai dan bersifat khusus bagi anggota DPR dalam melaksanakan fungsi dan hak konstitusionalnya adalah dengan

Pendapat Mahkamah Konstitusi pada angka 3.23 Putusan MK Nomor 73/PUU-IX/2011, hal. 73.

9 Pendapat Mahkamah Konstitusi pada angka 3.16 Putusan MK Nomor 76/PUU-XII/2014, hal. 105 dan Putusan MK Nomor 16/PUU-XVI/2018, hal. 21. diperlukannya persetujuan atau izin tertulis dari Presiden dalam hal anggota DPR tersebut dipanggil dan dimintai keterangan karena diduga melakukan pidana. Hal ini penting sebagai salah satu fungsi dan upaya menegakkan mekanisme checks and balances antara pemegang kekuasaan legislatif dengan pemegang kekuasaan eksekutif, sehingga Mahkamah berpendapat bahwa izin seharusnya berasal dari Presiden bukan berasal dari Mahkamah Kehormatan Dewan". ${ }^{10}$

Pendapat MK dalam putusan perkara Nomor 125/PUU-XII/2015 menyebutkan:

"Bahwa prosedur izin sebelum memeriksa pejabat negara dalam hal ini komisioner Komisi Yudisial yang tercantum dalam Pasal 10 ayat (1) UU KY dan Hakim Agung yang tercantum dalam Pasal 17 ayat (1) UU MA adalah dalam rangka melindungi harkat dan martabat serta wibawa pejabat negara dan lembaga negara agar diperlakukan secara hati-hati, cermat dan tidak sembrono serta tidak sewenang-wenang". ${ }^{11}$

Berdasarkan pendapat MK yang pertama, esensi persetujuan tertulis presiden kepada kepala daerah hanya agar sebagai pimpinan dari para kepala daerah, presiden mengetahui adanya pimpinan suatu daerah akan mengalami proses hukum yang akan membatasi ruang geraknya sehinga yang bersangkutan tidak dapat menjalankan tugasnya dengan baik. Putusan MK tersebut, meskipun untuk kepala daerah, namun dapat digunakan sebagai alat untuk menganalisis esensi persetujuan presiden dengan membandingkan antara pejabat yang berada di bawah presiden dengan yang sejajar dengan presiden.

Sementara pendapat MK mengenai persetujuan presiden terhadap proses pidana anggota DPR yang bukan bawahan presiden adalah:

1) perlindungan hukum yang memadai dan proporsional, sehingga anggota DPR tidak dengan mudah diproses pidana pada saat dan/atau dalam rangka melaksanakan fungsi dan kewenangan konstitusionalnya,

10 Pendapat Mahkamah Konstitusi pada angka 3.19 Putusan MK Nomor 76/PUU-XII/2014, hal. 106.

11 Pendapat Mahkamah Konstitusi pada angka 3.8 huruf e Putusan MK Nomor 125/PUU-XIII/2015, hal. 32. 
sepanjang dilakukan dengan itikad baik dan penuh tanggung jawab;

2) Dalam konteks izin seharusnya dikeluarkan oleh presiden, bukan oleh Mahkamah Kehormatan Dewan, MK berpendapat hal tersebut sebagai salah satu fungsi dan upaya menegakkan mekanisme checks and balances antara pemegang kekuasaan legislatif dengan pemegang kekuasaan eksekutif, sehingga izin seharusnya berasal dari presiden bukan berasal dari Mahkamah Kehormatan Dewan.

Kemudian pendapat MK mengenai persetujuan presiden terhadap proses pidana komisioner KY dan hakim agung adalah dalam rangka melindungi harkat dan martabat serta wibawa pejabat negara dan lembaga negara agar diperlakukan secara hati-hati, cermat, dan tidak sembrono, serta tidak sewenang-wenang. Pendapat-pendapat MK tersebut akan dikaji lebih lanjut.

Putusan MK dalam perkara Nomor 73/ PUU-IX/2011 membatalkan ketentuan mengenai tindakan penyelidikan dan penyidikan kepada kepala daerah dan wakil kepala daerah dilaksanakan setelah adanya persetujuan tertulis dari presiden atas permintaan penyidik, namun persetujuan tertulis presiden tetap diperlukan apabila tindakan penyidikan dilanjutkan dengan penahanan. Pendapat MK bahwa esensi persetujuan tertulis agar presiden mengetahui ada kepala daerah yang menjalani proses hukum tidak tepat, karena untuk sekedar "mengetahui" maka terminologinya bukan "persetujuan", melainkan cukup "pemberitahuan".

Persetujuan sebelum kegiatan dilaksanakan sama artinya dengan izin. Penyidik yang akan menahan kepala daerah perlu mendapatkan persetujuan presiden, artinya penyidik memerlukan izin presiden, bukan sekedar melaporkan atau memberitahukan. Presiden memiliki kewenangan untuk memberikan atau tidak memberikan izin. Izin memiliki implikasi yuridis, yaitu tindakan tidak dapat dilaksanakan apabila izin tidak dikeluarkan.

Putusan MK dalam perkara Nomor 76/ PUU-XII/2014 dan 16/PUU-XVI/2018 pada intinya menyatakan bahwa persetujuan terhadap anggota DPR yang diduga melakukan tindak pidana merupakan kewenangan presiden, bukan berdasar persetujuan atau pertimbangan Mahkamah Kehormatan Dewan. Pendapat MK bahwa esensi atau tujuan kewenangan presiden untuk memberikan persetujuan terhadap anggota DPR yang diduga melakukan tindak pidana adalah perlindungan hukum dan sebagai mekanisme checks and balances juga tidak tepat.

Menurut C.J. Ville, checks and balances memiliki korelasi yang berkaitan dengan doktrin pemisahan kekuasaan. ${ }^{12}$ Checks and balances merupakan konsepsi gabungan kekuasaan yang menginginkan tiga cabang kekuasaan negara saling membatasi satu sama lain. Checks adalah fungsi mengontrol satu kekuasaan dengan kekuasaan lainnya, dan fungsi yang berfaedah menciptakan keseimbangan (balance) terhadap kekuasaan lainnya. Prinsip doktrin tersebut memberikan kekuasaan konstitusional untuk mengimbangi fungsi kekuasaan satu dengan lainnya. Saling mengawasi dan mengimbangi menyatu dalam fungsi legislatif, fungsi eksekutif, dan yudikatif, yang kemudian memberikan tiga kekuasaan mengimbangi tiga kekuasaan lainnya yang berfungsi untuk mendominasi antara satu dan lainnya. ${ }^{13}$

Persetujuan presiden bukan hanya untuk anggota DPR yang diduga melakukan tindak pidana, melainkan juga untuk hakim agung, hakim konstitusi, dan anggota BPK. Perlindungan hukum pejabat-pejabat tersebut tidak seharusnya bergantung pada diberikannya persetujuan atau tidak diberikannya persetujuan oleh presiden yang sifatnya subjektif, karena hal tersebut akan dimaknai sebagai intervensi dalam proses hukum. Prinsip independensi peradilan merupakan hal penting dalam negara hukum. Peradilan yang bebas dan tidak memihak adalah kekuasaan peradilan yang dilakukan oleh hakim (peradilan) untuk menyelesaikan suatu pelanggaran hukum (baik dari alat-alat negara itu sendiri maupun dari warga negara)

\footnotetext{
12 Ibnu Sina Chandranegara, "Penuangan Checks and Balances ke dalam Konstitusi", Jurnal Konstitusi, Vol. 13, No. 3, September 2016, hal. 555.

13 Ibnu Sina Chandranegara, "Penuangan...", hal. 560.
} 
atau perselisihan hukum antara warga negara, harus bebas dari segala macam pengurus atau campur tangan dari mana pun datangnya dan dalam bentuk apa pun juga. ${ }^{14}$

Persetujuan presiden juga tidak dapat dikatakan sebagai mekanisme checks and balances karena presiden tidak sedang melakukan kontrol dan menyeimbangkan pelaksanaan fungsi lembaga lain. Kewenangan presiden memberikan persetujuan tersebut lebih kepada melakukan kontrol terhadap tindakan yang dilakukan oleh institusi ada lembaga yang berada di ranah eksekutif yang menyelenggarakan fungsi penyelidikan, penyidikan, dan penuntutan, yaitu kepolisian dan kejaksaan. Kontrol presiden itu pun seharusnya bukan dalam konteks intervensi terhadap penegakan hukum di luar ketentuan peraturan perundang-undangan. Apabila dikatakan hal tersebut sebagai mekanisme saling kontrol antara presiden dengan lembaga legislatif dan yudikatif tidak tepat, mengingat kewenangan memberikan persetujuan untuk proses pidana anggota DPR, hakim agung, hakim konstitusi, dan anggota BPK menumpuk di tangan presiden.

Pendapat MK dalam putusan perkara Nomor 125/PUU-XIII/2015 menyatakan bahwa izin dari presiden dalam rangka melindungi harkat dan martabat serta wibawa pejabat negara dan lembaga negara agar diperlakukan secara hati-hati, cermat dan tidak sembrono serta tidak sewenang-wenang. Hal ini juga tidak tepat karena ada mekanisme praperadilan yang dapat digunakan, tanpa harus dikoreksi oleh presiden dengan mekanisme pemberian persetujuan atau tidak memberikan persetujuan terhadap tindak lanjut proses tersebut.

Selain berdasarkan pendapat MK, esensi dari persetujuan presiden terhadap proses pidana anggota DPR juga dapat ditelusuri dari sejarah pengaturan mengenai ketentuan tersebut. Beberapa undang-undang pada masa lalu mengatur mengenai hal ini, antara lain Undang-Undang Nomor 75 Tahun 1954

\footnotetext{
14 Abdul Mukhtie Fadjar, Sejarah, Elemen dan Tipe Negara Hukum, Malang: Setara Press, 2016, hal. 55.
}

tentang Acara Pidana Khusus untuk Anggota Dewan Perwakilan Rakyat dan UndangUndang Nomor 13 Tahun 1970 tentang Tata Cara Tindakan Kepolisian terhadap AnggotaAnggota/Pimpinan Majelis Permusyawaratan Rakyat Sementara dan Dewan Perwakilan Rakyat Gotong-Royong.

Berdasarkan Undang-Undang tentang Acara Pidana Khusus untuk anggota DPR disebutkan bahwa seorang anggota DPR yang berada di gedung DPR hanya dapat ditangkap atau ditahan setelah mendapat persetujuan Jaksa Agung dan maksud tentang penangkapan dan penahanan itu diberitahukan kepada Ketua DPR, kecuali jika ia tertangkap tangan melakukan suatu tindakan pidana. ${ }^{15}$ Di dalam penjelasan umum undang-undang ini disebutkan:

"Maksud Undang-undang ini ialah supaya anggota Dewan Perwakilan Rakyat dapat dan leluasa melakukan tugasnya sebagai anggota Dewan Perwakilan Rakyat dengan sebaik-baiknya sehingga ia tidak perlu khawatir akan tindakan sewenang-wenang dari alat-alat Negara waktu ia melakukan tugasnya itu; dengan lain perkataan jangan hendaknya ada "willekeur" terhadap penahanan atau penangkapan anggota Dewan Perwakilan Rakyat. Di dalam menentukan hakhak khusus anggota Dewan Perwakilan Rakyat itu, maka sudah seharusnyalah bahwa hak-hak istimewa itu tidak terlalu berlainan dengan hakhak warganegara lainnya; dalam pada itu tidak pula dilupakan bahwa anggota Dewan Perwakilan Rakyat di dalam melakukan tugasnya, memang mempunyai kedudukan istimewa. Di dalam Undang-undang ini materi yang bersangkutan tidak diatur "uitputtend", sebab adalah bijaksana kiranya melihat dahulu perkembangan masyarakat dan prakteknya peraturan ini di negara kita".

Undang-Undang tentang Acara Pidana Khusus untuk anggota DPR ini kemudian diganti dengan Undang-Undang Nomor 13 Tahun 1970 tentang Tata Cara Tindakan Kepolisian terhadap Anggota-Anggota/Pimpinan Majelis Permusyawaratan Rakyat Sementara dan Dewan Perwakilan Rakyat Gotong-Royong.

$15 \quad$ Pasal 1 ayat (2) Undang-Undang Nomor 75 Tahun 1954 tentang Hukum Acara Pidana Khusus untuk Anggota DPR. 
Berdasarkan undang-undang ini, tindakan kepolisian terhadap Anggota/Pimpinan Majelis Permusyawaratan Rakyat Sementara dan Dewan Perwakilan Rakyat Gotong-Royong dilakukan atas persetujuan presiden dengan ketentuan: untuk anggota yang berasal dari kalangan sipil pelaksanaannya atas perintah jaksa agung, sementara untuk anggota yang berasal dari kalangan militer pelaksanaannya atas perintah menteri pertahanan dan keamanan/panglima angkatan bersenjata. ${ }^{16}$

Kedua undang-undang tersebut merupakan undang-undang dalam konteks masa lalu. Pada pengaturan berdasarkan Undang-Undang Nomor 75 Tahun 1954, yang memberikan persetujuan hanyajaksaagung, namun kemudian berdasarkan Undang-Undang Nomor 13 Tahun 1970 persetujuan diberikan oleh presiden. Esensi persetujuan tersebut sebagaimana disebutkan dalam penjelasan Undang-Undang Nomor 75 Tahun 1954, supaya anggota DPR dapat dan leluasa melakukan tugasnya dengan sebaikbaiknya tanpa perlu khawatir akan tindakan sewenang-wenang dari alat-alat negara sewaktu menjalankan tugasnya. Penjelasan juga menyebutkan jangan ada willekeur (tindakan sewenang-wenang) terhadap penahanan atau penangkapan anggota DPR.

Berdasarkan penjelasan undang-undang terlihat bahwa keistimewaan diberikan berkaitan dengan hak imunitas anggota DPR. Hak imunitas tidak dimiliki oleh hakim agung, hakim konstitusi, dan anggota BPK. Hak imunitas secara eksplisit hanya diberikan oleh UUD 1945 kepada anggota DPR dan penggunaan hak imunitas tersebut telah diberi batasan oleh undang-undang. Tidak ada undang-undang khusus yang mengatur mengenai hukum acara untuk hakim agung, hakim konstitusi, dan anggota BPK.

Kajian berikutnya mengenai esensi dari persetujuan presiden untuk proses pidana dapat dilakukan dengan merunut sumber

\footnotetext{
Pasal 3 Undang-Undang Nomor 13 Tahun 1970 tentang Tata Cara Tindakan Kepolisian Terhadap AnggotaAnggota/Pimpinan Majelis Permusyawaratan Rakyat Sementara dan Dewan Perwakilan Rakyat GotongRoyong.
}

kewenangan presiden dalam UUD 1945. Berdasarkan hukum administrasi, kewenangan presiden memang tidak perlu dipermasalahkan lagi sepanjang telah jelas disebutkan dalam undang-undang. Berdasarkan ilmu perundangundangan, validitas suatu norma dalam undangundang bersumber dari norma di atasnya, sehingga dalam hal ini perlu dicari sumber kewenangan tersebut dalam ketentuan UUD 1945. Hal ini sesuai dengan teori jenjang norma dalam kaitannya dengan suatu negara. Hans Nawiasky dalam bukunya Allgemeine Rechtslehre mengemukakan bahwa sesuai dengan teori Hans Kelsen, suatu norma hukum negara selalu berlapis-lapis dan berjenjang, yakni norma yang di bawah berlaku, berdasar, dan bersumber pada norma yang lebih tinggi dan begitu seterusnya sampai pada suatu norma yang tertinggi yang disebut norma dasar. ${ }^{17}$

Apakah dasar kewenangan presiden memberikan persetujuan terhadap proses pidana pejabat negara merupakan turunan dari presiden sebagai pemegang kekuasaan pemerintahan atau hak presiden memberikan grasi, rehabilitasi, amnesti, dan abolisi? Presiden sebagai pemegang kekuasaan pemerintahan diatur dalam Pasal 4 ayat (1) UUD 1945, sedangkan hak presiden memberikan grasi, rehabilitas, amnesti, dan abolisi diatur dalam Pasal 14 UUD 1945.

Pemerintahan dapat diartikan secara luas (government in broader sense) dan secara sempit (government in narrower sense). ${ }^{18}$ Pemerintahan dalam arti luas tidak terbatas pada lembaga eksekutif, ${ }^{19}$ sementara yang dimaksud dengan

17 Maria Farida Indrati, et.all, Laporan Kompendium Bidang Hukum Perundang-Undangan, Jakarta: Departemen Hukum dan HAM RI, 2008, hal. 25-26.

18 Sri Soemantri Martosoewignjo, Hukum Tata Negara Indonesia, Pemikiran dan Pandangan, Cet. ke-2, Bandung: PT. Remaja Rosdakarya, 2015, hal. 353.

19 Menurut C. F. Strong, pemerintahan dalam arti luas merupakan setiap aktivitas badan-badan publik yang terdiri dari aktivitas-aktivitas atau pun kegiatan eksekutif, legislatif, dan yuridis dalam upaya mencapai tujuan sebuah negara. Pemerintahan dalam arti sempit apabila pemerintahan merupakan setiap bentuk aktivitas kegiatan badan publik dan hanya terdiri dari badan eksekutif. C.F. Strong, Modern Political Constitutions, London: Sidgwick and Jackson Ltd, 1960 dalam W.MHery Susilowati, “Sistem 
pemerintah dalam arti yang sempit adalah presiden yang dibantu wakil presiden dan menteri-menteri negara. ${ }^{20}$ Berkaitan dengan pemerintahan dalam arti sempit, presiden merupakan pemegang kekuasaan pemerintahan di bidang eksekutif. Kepolisian Negara Republik Indonesia dan Kejaksaan Republik Indonesia merupakan institusi setingkat menteri yang berada di bawah presiden. Kapolri dan jaksa agung diangkat dan diberhentikan oleh presiden, meskipun untuk pengangkatan Kapolri harus dengan persetujuan DPR.

Fungsi penyelidikan dan penyidikan merupakan salah satu kewenangan Polri. Kapolri pernah mengeluarkan Surat Kapolri Nomor: B/3120/VI/2016/Bareskrim tertanggal 21 Juni 2016 perihal arahan Pembinaan Fungsi (Binfung) dalam melakukan tindakan kepolisian terhadap pejabat negara. ${ }^{21}$ Di dalam Surat Kapolri tersebut, persyaratan pengajuan surat permohonan persetujuan tertulis kepada presiden dan menteri dalam negeri sebagai berikut.

a. Syarat administrasi

Direktur jajaran Bareskrim Polri atau Kapolda mengajukan surat permohonan persetujuan tertulis Presiden atau Menteri Dalam Negeri yang ditujukan kepada Kapolri u.p. Kabareskrim Polri dilengkapi dengan:

1) Laporan Polisi;

2) Surat Perintah Tugas;

3) Laporan Hasil Penyelidikan;

4) Surat Perintah Penyidikan;

5) Surat Pemberitahuan Dimulainya Penyidikan (SPDP);

6) Laporan kemajuan penyidikan (Lapju/ resume)

7) Hasil audit BPK atau BPKP tentang kerugian negara (khusus kasus Tipidkor);

Pemerintahan Indonesia Menurut UUD 1945 (Suatu Kajian Teoritis)", Jurnal Perspektif, Vol. 9, No. 3, Ed. Juli Tahun 2003, hal. 252.

20 Sri Soemantri Martosoewignjo, Hukum Tata Negara Indonesia,....", Ibid.

21 "Birokrasi Perijinan Penyidikan terhadap Pejabat Penyelenggara Negara”, https://jurnalsrigunting.wordpress. com/2012/02/08/birokrasi-perijinan-penyidikanterhadap-pejabat-penyelenggara-negara, diakses tanggal 10 September 2018.
8) Notulasi gelar perkara di tingkat Direktorat Bareskrim Polri;

9) Notulasi gelar perkara khusus di tingkat Polda yang dihadiri unsurunsur pengawasan internal Polda;

b. Syarat material

Perkara yang diajukan permohonan tertulis untuk dilakukan tindakan kepolisian terhadap anggota MPR, DPR, DPD, dan kepala daerah kepada Presiden, terhadap anggota DPRD provinsi kepada menteri dalam negeri, dan terhadap anggota DPRD kabupaten/kota kepada Gubernur adalah:

1) Perkara pidana dengan bukti permulaan yang cukup (sebagai saksi atas perkara yang telah cukup bukti terhadap tersangkanya)

2) Dari keterangan para saksi, tersangka, dan barang bukti, yang bersangkutan diduga keras sebagai tersangka utama atau tersangka penyertaan/membantu sebagaimana dimaksud Pasal 55 dan Pasal 56 KUHP.

Alur proses permohonan persetujuan tertulis Presiden atau Menteri Dalam Negeri di Biro Pengawasan Penyidikan (Birowassidik) Bareskrim Polri:

a. Menerima surat dan berkas syarat administrasi penyidikan (Mindik) pengajuan permohonan persetujuan tertulis Presiden/Menteri Dalam Negeri dari Penyidik;

b. Meneliti administrasi penyidikan dan substansi perkara;

c. Melaksanakan gelar perkara khusus;

d. Mengajukan permohonan persetujuan tertulis;

1) Untuk melakukan tindakan kepolisian kepada anggota MPR, DPR, DPD, dan Kepala Daerah Gubernur/Wakil Gubernur yang ditandatangani oleh Kapolri ditujukan langsung kepada Presiden dan ditembuskan kepada Sekretaris Kabinet RI;

2) Untuk melakukan tindakan kepolisian terhadap anggota DPRD provinsi, Bupati dan/atau Wakil Bupati, 
Walikota dan/atau Wakil Walikota yang ditandatangani oleh Kapolri ditujukan langsung kepada Menteri Dalam Negeri.

e. Mengirimkan asli tanda terima penmgiriman surat permohonan persetujuan tertulis Presiden kepada Penyidik dengan tanggal penerimaan surat permohonan tersebut menjadi start perhitungan waktu 30 (tiga puluh) hari permohonan, pemanggilan dan permintaan keterangan untuk penyidikan dapat dilakukan apabila surat permohonan tersebut belum/tidak dijawab;

f. Mengirimkan surat jawaban Presiden/ Menteri Dalam Negeri atas persetujuan tertulis kepada penyidik yang menangani perkaranya.

Di dalam implementasinya, terdapat beberapa kendala yang dihadapi penyidik Polri dalam menempuh birokrasi perizinan tersebut, yaitu: (a) panjangnya birokrasi yang harus ditempuh; (b) lamanya surat persetujuan tersebut diterima; (c) masih sering terjadi kontroversi antara Polri, Kejaksaan dan instansi terkait; (d) keraguan penyidik dalam menindaklanjuti penyidikan tanpa adanya surat persetujuan; dan (e) rentan terhadap terjadinya penyimpangan dan penyalahgunaan selama proses berlangsung. 22 Proses administrasi ini apabila dikaitkan dengan kewenangan presiden sebagai pemegang kekuasaan pemerintahan (dalam arti sempit) menunjukkan adanya inefisiensi karena birokrasi yang panjang dan berbelit-belit. Proses administrasi ini juga rentan terhadap kesan intervensi dalam proses penegakan hukum.

Dalam konteks kekuasaan presiden di bidang yudisial, terdapat hak presiden untuk memberikan grasi, rehabilitasi, amnesti, dan abolisi. Grasi pada dasarnya merupakan pemberian dari presiden dalam bentuk pengampunan yang berupa perubahan, peringanan, pengurangan, atau penghapusan pelaksanaan putusan pengadilan kepada terpidana. ${ }^{23}$ Kendati pemberian grasi dapat

\footnotetext{
$22 \quad$ Ibid.,

23 Pasal 1 angka 1 Undang-Undang Nomor 22 Tahun 2002 tentang Grasi.
}

mengubah, meringankan, mengurangi, atau menghapuskan kewajiban menjalani pidana yang dijatuhkan pengadilan, tidak berarti menghilangkan kesalahan dan juga bukan merupakan rehabilitasi terhadap terpidana. ${ }^{24}$ Kondisi ini berbeda dan tidak memiliki korelasi dengan pemberian persetujuan presiden, karena statusnya bukan terpidana melainkan masih dalam status tersangka.

Ketentuan mengenai abolisi lebih menyerupai karena belum ada status sebagai terpidana. Undang-undang mengenai amnesti dan abolisi yang pernah diundangkan adalah Undang-Undang Nomor 11 Tahun 1954 tentang Amnesti dan Abolisi sebagai pelaksanaan ketentuan Pasal 96 dan Pasal 107 Undang-Undang Dasar Sementara Republik Indonesia. Di dalam undang-undang disebutkan bahwa presiden, atas kepentingan negara, dapat memberi amnesti dan abolisi kepada orangorang yang telah melakukan sesuatu tindakan pidana setelah mendapat nasihat tertulis dari MA yang menyampaikan nasihat itu atas permintaan Menteri Kehakiman.

Undang-undang Nomor 11 Tahun 1954 memberikan amnesti dan abolisi kepada semua orang yang sebelum tanggal 27 Desember 1949 telah melakukan sesuatu tindak pidana yang nyata akibat dari persengketaan politik antara Republik Indonesia (Yogyakarta) dan Kerajaan Belanda. Dengan pemberian amnesti, semua akibat hukum pidana terhadap orang-orang tersebut dihapuskan. Penuntutan terhadap orang-orang yang tersebut ditiadakan dengan pemberian abolisi.

Dengan demikian, yang lebih menyerupai persetujuan tertulis presiden (karena belum ada putusan pengadilan) adalah abolisi yang menghapuskan tuntutan terhadap seseorang atau sekelompok orang, namun tidak tepat pula apabila dikatakan sumber kewenangan persetujuan tertulis presiden dalam proses pidana pejabat negara utama diturunkan dari hak abolisi yang dimiliki presiden. Hal

Bobby Rantung, "Kewenangan Presiden Dalam Memberikan Grasi Kepada Terpidana Mati Kasus Narkoba”, Lex Privatum, Vol. 4, No. 4, April 2016, hal. 136. 
ini karena dalam pemberian abolisi, presiden harus mendapatkan pertimbangan DPR atau bukan bertindak sendiri dan sifatnya lebih ke politis dibandingkan dengan yuridis, serta pemberiannya bukan hanya terbatas pada pejabat negara.

Esensi persetujuan presiden dalam proses pidana terhadap pejabat negara utama tidak memeroleh argumentasi yang cukup kuat. Beberapa esensi persetujuan presiden sebagaimana yang tertuang di dalam putusan MK masih memiliki banyak kelemahan. Validitas norma pengaturan persetujuan presiden dalam proses pidana juga tidak ditemukan rujukannya yang tepat dalam UUD 1945, kecuali justru malah menyiratkan adanya intervensi presiden atau paling tidak memperpanjang birokrasi dalam proses penegakan hukum.

Salah satu argumentasi yang dapat diterima adalah proses hukum terhadap pejabat negara akan berpengaruh pada jalannya roda pemerintahan, namun solusinya tidak tepat apabila dengan memberikan kewenangan kepada presiden untuk memberikan atau tidak memberikan persetujuan. Solusi yang dapat dilakukan adalah dengan membuat aturan hukum mengenai pemberhentian sementara atau penggantian. Permasalahannya, seringkali proses hukum memerlukan waktu yang sangat lama sampai dengan mempunyai kekuatan hukum tetap, sehingga kepastian hukum mengenai status pejabat tersebut menjadi terkatung-katung bahkan mungkin sampai berakhir masa jabatannya.

Menghidupkan kembali forum previligiatum merupakan keniscayaan yang dapat dipikirkan untuk menjadi salah satu opsi, sebagaimana Konstitusi RIS dan UUDS pernah mengatur mengenai peradilan khusus bagi pejabatpejabat negara. Forum previligiatum merupakan pengadilan khusus ketatanegaraan bagi pejabat tinggi negara yang diindikasikan melanggar hukum. ${ }^{25}$ UUDS merumuskan dengan ketentuan:

25 Nur Habibi, "Politieke Beslissing dalam Pemakzulan Presiden Republik Indonesia", Jurnal Cita Hukum, Vol. 3, No. 2, Desember 2015, hal. 327-338.
"Presiden, Wakil-Presiden, Menteri-menteri, Ketua, Wakil-Ketua dan Anggauta Dewan Perwakilan Rakjat, Ketua, Wakil-Ketua dan Anggauta Mahkamah Agung, Djaksa Agung pada Mahkamah Agung, Ketua, Wakil-Ketua, dan Anggauta Dewan Pengawas Keuangan, Presiden Bank-Sirkulasi dan djuga pegawai-pegawai, anggauta-anggauta, madjelis-madjelis tinggi dan pedjabat-pedjabat lain jang ditundjuk dengan undang-undang, diadili dalam tingkat pertama dan tertinggi djuga oleh Mahkamah Agung, pun sesudah mereka berhenti, berhubung dengan kedjahatan dan pelanggaran-djabatan serta kedjahatan dan pelanggaran lain jang ditentukan dengan undang-undang dan jang dilakukannja dalam masa pekerdjaannja, ketjuali djika ditetapkan lain dengan undang-undang."

Konstitusi RIS merumuskan dengan ketentuan:

"Presiden, Menteri2, Ketua dan anggota2 Senat, Ketua dan anggota2 Dewan Perwakilan Rakjat, Ketua, Wakil-Ketua dan anggota2 Mahkamah Agung, Djaksa Agung pada Mahkamah ini, Ketua, Wakil-Ketua dan anggota2 Dewan Pengawas Keuangan, Presiden Bank-Sirkulasi sertapegawai2, anggota2 madjelis2 tinggi dan pendjabat2 lain jang ditundjuk dengan undang-undang federal, diadili dalam tingkat pertama dan tertinggi djuga di muka Mahkamah Agung, pun sesudah mereka berhenti, berhubung dengan kedjahatan- dan pelanggarandjabatan serta kedjahatan dan pelanggaran lain ditentukan dengan undang-undang federal dan jang dilakukannja dalam masa pekerdjaannja, ketjuali djika ditetapkan lain dengan undangundang federal." 27

Peradilan khususdenganhukumacarakhusus bagi pejabat negara tidak akan bertentangan dengan prinsip equality before the law, dan justru akan merefleksikan prinsip peradilan yang cepat, sederhana, dan biaya ringan.

\section{Sinkronisasi Pengaturan Mengenai Persetujuan Presiden}

Pengaturan mengenai persetujuan presiden dalam proses pidana terhadap pejabat negara utama yang diatur dalam beberapa undangundang dapat digambarkan dalam tabel berikut ini.

\footnotetext{
26 Pasal 106 ayat (1) UUDS.

27 Pasal 148 ayat (1) Konstitusi RIS
} 
Tabel 1. Perbandingan Pengaturan Persetujuan Presiden

\begin{tabular}{|c|c|c|c|}
\hline JABATAN & $\begin{array}{c}\text { KETENTUAN } \\
\text { PROSES PIDANA }\end{array}$ & PENGECUALIAN & TINDAK LANJUT \\
\hline $\begin{array}{l}\text { HAKIM } \\
\text { AGUNG }\end{array}$ & $\begin{array}{l}\text { Dapat ditangkap atau } \\
\text { ditahan hanya atas } \\
\text { perintah Jaksa Agung } \\
\text { setelah mendapat } \\
\text { persetujuan presiden }\end{array}$ & $\begin{array}{l}\text { a. tertangkap tangan melakukan tindak } \\
\text { pidana kejahatan; atau } \\
\text { b. berdasarkan bukti permulaan yang } \\
\text { cukup, disangka telah melakukan } \\
\text { tindak pidana kejahatan yang } \\
\text { diancam dengan pidana mati, atau } \\
\text { tindak pidana kejahatan terhadap } \\
\text { keamanan negara. }\end{array}$ & $\begin{array}{l}\text { Pelaksanaan penangkapan } \\
\text { atau penahanan tersebut } \\
\text { selambat-lambatnya dalam } \\
\text { waktu } 2 \text { (dua) kali } 24 \text { (dua } \\
\text { puluh empat) jam harus } \\
\text { dilaporkan kepada Jaksa } \\
\text { Agung. }\end{array}$ \\
\hline $\begin{array}{l}\text { HAKIM } \\
\text { KONSTITUSI }\end{array}$ & $\begin{array}{l}\text { Hanya dapat } \\
\text { dikenakan tindakan } \\
\text { kepolisian atas } \\
\text { perintah Jaksa Agung } \\
\text { setelah mendapat } \\
\text { persetujuan tertulis } \\
\text { presiden }\end{array}$ & $\begin{array}{l}\text { a. tertangkap tangan melakukan tindak } \\
\text { pidana; atau } \\
\text { b. berdasarkan bukti permulaan yang } \\
\text { cukup disangka telah melakukan } \\
\text { tindak pidana kejahatan yang } \\
\text { diancam dengan pidana mati atau } \\
\text { tindak pidana kejahatan terhadap } \\
\text { keamanan negara. }\end{array}$ & Tidak diatur \\
\hline $\begin{array}{l}\text { ANGGOTA } \\
\text { MPR }\end{array}$ & Tidak diatur & Tidak diatur & Tidak diatur \\
\hline $\begin{array}{l}\text { ANGGOTA } \\
\text { DPR }\end{array}$ & $\begin{array}{l}\text { Pemanggilan } \\
\text { dan permintaan } \\
\text { keterangan kepada } \\
\text { anggota DPR yang } \\
\text { diduga melakukan } \\
\text { tindak pidana yang } \\
\text { tidak sehubungan } \\
\text { dengan pelaksanaan } \\
\text { tugas sebagaimana } \\
\text { dimaksud dalam Pasal } \\
224 \text { harus } \\
\text { mendapatkan } \\
\text { persetujuan tertulis } \\
\text { dari presiden }{ }^{28}\end{array}$ & $\begin{array}{l}\text { a. tertangkap tangan melakukan tindak } \\
\text { pidana; } \\
\text { b. disangka melakukan tindak pidana } \\
\text { kejahatan yang diancam dengan } \\
\text { pidana mati atau pidana penjara } \\
\text { seumur hidup atau tindak pidana } \\
\text { kejahatan terhadap kemanusiaan } \\
\text { dan keamanan negara berdasarkan } \\
\text { bukti permulaan yang cukup; atau } \\
\text { c. disangka melakukan tindak pidana } \\
\text { khusus. } \\
\text { (antara lain meliputi tindak pidana } \\
\text { korupsi, tindak pidana terorisme, } \\
\text { pelanggaran HAM berat, tindak } \\
\text { pidana perdagangan orang, tindak } \\
\text { pidana penyalahgunaan narkotika) }\end{array}$ & \\
\hline $\begin{array}{l}\text { ANGGOTA } \\
\text { DPD }\end{array}$ & Tidak diatur & Tidak diatur & Tidak diatur \\
\hline $\begin{array}{l}\text { ANGGOTA } \\
\text { BPK }\end{array}$ & $\begin{array}{l}\text { Tindakan kepolisian } \\
\text { terhadap anggota BPK } \\
\text { guna pemeriksaan } \\
\text { suatu perkara dilakukan } \\
\text { dengan perintah Jaksa } \\
\text { Agung setelah terlebih } \\
\text { dahulu mendapat } \\
\text { persetujuan tertulis } \\
\text { presiden. }\end{array}$ & $\begin{array}{l}\text { a. tertangkap tangan melakukan tindak } \\
\text { pidana kejahatan, atau; } \\
\text { b. berdasarkan bukti permulaan yang } \\
\text { cukup, disangka telah melakukan } \\
\text { tindak pidana kejahatan yang } \\
\text { diancam dengan pidana mati, atau } \\
\text { tindak pidana kejahatan terhadap } \\
\text { keamanan negara. }\end{array}$ & $\begin{array}{l}\text { Terhadap tindakan yang } \\
\text { dikecualikan tersebut, dalam } \\
\text { waktu } 1 \text { X } 24 \text { (satu kali dua } \\
\text { puluh empat) jam harus } \\
\text { dilaporkan kepada Jaksa } \\
\text { Agung yang berkewajiban } \\
\text { untuk memberitahukan } \\
\text { penahanan tersebut kepada } \\
\text { presiden, DPR, dan BPK. }\end{array}$ \\
\hline PRESIDEN & Tidak diatur & Tidak diatur & Tidak diatur \\
\hline \multicolumn{4}{|c|}{ Sumber: UU MD3, UU MA, UU MK, dan UU BPK. } \\
\hline
\end{tabular}

28 Perubahan berdasarkan Putusan MK Nomor 16/PUU. XVI/2018. 
Terdapat tiga pejabat negara utama yang tidak diatur di dalam undang-undang berkaitan dengan bagaimana proses pidana dilakukan apabila yang bersangkutan melakukan tindak pidana, yaitu presiden, anggota MPR, dan anggota DPD. Ketentuan apabila presiden melakukan pelanggaran hukum diatur di dalam Pasal 7A dan Pasal 7B UUD 1945, namun pengaturan ini sebenarnya terkait dengan proses ketatanegaraan (pemakzulan), bukan proses pidana. Proses pidana bagi presiden yang melakukan pelanggaran hukum belum cukup diatur dan akan menimbulkan permasalahan interpretasi mengenai hukum acaranya apabila hal tersebut terjadi. Interpretasi yang muncul, misalnya apakah DPR bertindak sebagai penyidik ketika akan mengajukan pernyataan pendapat bahwa presiden melakukan pelanggaran hukum dan apakah MK mengadili "pendapat" DPR sekaligus mengadili "pelanggaran hukum" yang dilakukan oleh presiden.

Pengaturan mengenai anggota MPR, anggota DPR, dan anggota DPD diatur dalam 1 (satu) undang-undang, yaitu UU MD3. Ketentuan mengenai penyidikan bagi anggota MPR dan anggota DPD tidak diatur di dalam UU MD3 yang berlaku sekarang ini. Di dalam UU MD3 sebelumnya, yaitu Undang-Undang Nomor 27 Tahun 2009, terdapat pengaturan penyidikan untuk anggota MPR (Pasal 66) dan untuk anggota DPD (Pasal 289) yang juga mensyaratkan persetujuan presiden. Terdapat dua kemungkinan mengapa untuk anggota MPR dan anggota DPD tidak diatur dalam UU MD3 yang baru. Pertama, UU MD3 yang baru mengubah ketentuan persetujuan presiden menjadi persetujuan Mahkamah Kehormatan Dewan. Kedua, kekurangcermatan dalam melakukan sinkronisasi pengaturan antara MPR, DPR, dan DPD.

UU MA mengatur bahwa Ketua, Wakil Ketua, Ketua Muda, dan Hakim Anggota Mahkamah Agung dapat ditangkap atau ditahan hanya atas perintah jaksa agung setelah mendapat persetujuan presiden, kecuali dalam hal: 29

$29 \quad$ Pasal 17 ayat (1) UU MA. a. tertangkap tangan melakukan tindak pidana kejahatan, atau;

b. berdasarkan bukti permulaan yang cukup, disangka telah melakukan tindak pidana kejahatan yang diancam dengan pidana mati, atau tindak pidana kejahatan terhadap keamanan negara.

Pelaksanaan penangkapan atau penahanan tersebut selambat-lambatnya dalam waktu 2 (dua) kali 24 (dua puluh empat) jam harus dilaporkan kepada jaksa agung. ${ }^{30}$

Sementara di dalam UU MK diatur bahwa hakim konstitusi hanya dapat dikenakan tindakan kepolisian atas perintah jaksa agung setelah mendapat persetujuan tertulis presiden, kecuali dalam hal: ${ }^{31}$

a. tertangkap tangan melakukan tindak pidana; atau

b. berdasarkan bukti permulaan yang cukup disangka telah melakukan tindak pidana kejahatan yang diancam dengan pidana mati atau tindak pidana kejahatan terhadap keamanan negara.

Di rumpun lembaga legislatif, terdapat tiga lembaga negara utama, yaitu MPR, DPR, dan DPD. Berbeda dengan lembaga yudisial yang memiliki dua undang-undang terpisah, lembaga legislatif diatur dalam satu undang-undang. Pengaturan mengenai proses pidana bagi pejabat negara hanya ditujukan kepada anggota DPR, tidak diatur untuk anggota MPR dan anggota DPD. Terdapat dua rumusan terkait dengan ketentuan persetujuan tersebut, yaitu Pasal 224 ayat (5) UU MD3 yang terkait imunitas DPR dan Pasal 245 ayat (1) UU MD3. Rumusan Pasal 224 ayat (5) UU MD3 menyebutkan:

"Pemanggilan dan permintaan keterangan kepada anggota DPR yang diduga melakukan tindak pidana sehubungan dengan pelaksanaan tugas sebagaimana dimaksud pada ayat (1), ayat (2), ayat (3) dan ayat (4) harus mendapatkan persetujuan tertulis dari Mahkamah Kehormatan Dewan".

\footnotetext{
Pasal 17 ayat (2) UU MA.

31 Pasal 6 ayat (2) UU MK.
} 
Ketentuan ini kemudian diajukan ke MK untuk diuji dan MK memutuskan ketentuan Pasal 224 ayat (5) bertentangan dengan UUD 1945 sepanjang tidak dimaknai pemanggilan dan permintaan keterangan kepada anggota DPR yang diduga melakukan tindak pidana sehubungan dengan pelaksanaan tugas sebagaimana dimaksud pada ayat (1), ayat (2), ayat (3) dan ayat (4) harus mendapatkan persetujuan tertulis dari presiden. ${ }^{32}$

Rumusan Pasal 245 ayat (1) di dalam Undang-Undang Nomor 17 tahun 2014 menyebutkan: "Pemanggilan dan permintaan keterangan untuk penyidikan terhadap anggota DPR yang diduga melakukan tindak pidana harus mendapat persetujuan tertulis dari Mahkamah Kehormatan Dewan". Pasal ini juga dibatalkan oleh MK sepanjang tidak dimaknai Pemanggilan dan permintaan keterangan untuk penyidikan terhadap anggota DPR yang diduga melakukan tindak pidana harus mendapat persetujuan tertulis dari presiden". ${ }^{33}$

Selanjutnya, melalui perubahan kedua Undang-Undang Nomor 17 Tahun 2014 dengan Undang-Undang Nomor 2 Tahun 2018, ketentuan Pasal 224 dan Pasal 245 mengalami perubahan. Pasal 224 menghapuskan ketentuan ayat (5), sedangkan Pasal 245 ayat (1) berubah menjadi:

"Pemanggilan dan permintaan keterangan kepada anggota DPR sehubungan dengan terjadinya tindak pidana yang tidak sehubungan dengan pelaksanaan tugas sebagaimana dimaksud dalam Pasal 224 harus mendapatkan persetujuan tertulis dari Presiden setelah mendapat pertimbangan dari Mahkamah Kehormatan Dewan".

Pasal ini kembali diajukan uji materi di MK dan kembali mengalami perubahan berdasarkan putusan MK. Perubahan tersebut dilakukan dengan pernyataan kontitusional bersyarat, yaitu pasal tersebut bertentangan dengan UUD 1945 sepanjang tidak dimaknai dengan pemanggilan dan permintaan keterangan kepada anggota DPR yang diduga melakukan tindak pidana yang tidak sehubungan dengan pelaksanaan

\footnotetext{
32 Putusan MK Nomor 76/PUU-XII/2014.
}

33 Putusan MK Nomor 76/PUU-XII/2014. tugas sebagaimana dimaksud dalam Pasal 224 harus mendapatkan persetujuan tertulis dari presiden". 34

Persetujuan tertulis tersebut tidak berlaku apabila anggota DPR: ${ }^{35}$

a. tertangkap tangan melakukan tindak pidana;

b. disangka melakukan tindak pidana kejahatan yang diancam dengan pidana mati atau pidana penjara seumur hidup atau tindak pidana kejahatan terhadap kemanusiaan dan keamanan negara berdasarkan bukti permulaan yang cukup; atau

c. disangka melakukan tindak pidana khusus. Di dalam penjelasan UU MD3 disebutkan bahwa yang dimaksud dengan tindak pidana khusus antara lain meliputi tindak pidana korupsi, tindak pidana terorisme, pelanggaran HAM berat, tindak pidana perdagangan orang, tindak pidana penyalahgunaan narkotika.

Di dalam UU BPK terdapat ketentuan dalam Bab V tentang Hak Keuangan/ Administratif dan Protokoler, Tindakan Kepolisian, Kekebalan, serta Larangan. Pada Bagian Kedua mengenai Tindakan Kepolisian diatur bahwa tindakan kepolisian terhadap anggota BPK guna pemeriksaan suatu perkara dilakukan dengan perintah Jaksa Agung setelah terlebih dahulu mendapat persetujuan tertulis presiden. $^{36}$ Anggota BPK dapat dikenakan tindakan kepolisian tanpa menunggu perintah jaksa agung atau persetujuan tertulis presiden, apabila: ${ }^{37}$

a. tertangkap tangan melakukan suatu tindak pidana; atau

b. disangka telah melakukan tindak pidana kejahatan yang diancam dengan pidana mati.

Terhadap tindakan yang dikecualikan tersebut, dalam waktu 1 X 24 (satu kali dua puluh empat) jam harus dilaporkan kepada jaksa agung

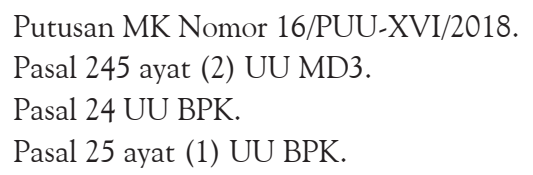


yang berkewajiban untuk memberitahukan penahanan tersebut kepada presiden, DPR, dan BPK. ${ }^{38}$

Dari existing law, terlihat adanya ketidaksinkronan atau inkonsistensi. Ketidaksinkronan tersebut terdapat dalam beberapa hal, yaitu:

1. Istilah dan Tahapan

Istilah yang digunakan untuk hakim agung adalah "ditangkap atau ditahan". Istilah yang digunakan untuk hakim konstitusi dan anggota BPK adalah "tindakan kepolisian". Istilah yang digunakan untuk anggota DPR, menggunakan frasa "pemanggilan dan permintaan keterangan kepada anggota DPR yang diduga melakukan tindak pidana". Pemilihan penggunaan istilah atau frasa tersebut sangat penting untuk kepastian hukum, yakni dalam hal apa, atau status apa, atau pada tahapan apa dalam proses pidana diperlukan persetujuan dari presiden.

Menurut KUHAP, penangkapan adalah suatu tindakan penyidik berupa pengekangan sementara waktu kebebasan tersangka atau terdakwa apabila terdapat cukup bukti guna kepentingan penyidikan atau penuntutan dan/ atau peradilan dalam hal serta menurut cara yang diatur dalam Undang-Undang Hukum Acara Pidana. ${ }^{39}$ Penahanan adalah penempatan tersangka atau terdakwa ditempat tertentu oleh penyidik atau penuntut umum atau hakim dengan penetapannya, dalam hal serta menurut cara yang diatur dalam KUHAP. ${ }^{40}$ Artinya, untuk ditangkap (kecuali tertangkap tangan) atau ditahan, tahapan dalam proses pidana sudah masuk dalam penyidikan dan hakim agung yang bersangkutan sudah ditetapkan menjadi tersangka. Secara a contrario, pada proses sebelum penangkapan dan penahanan, atau sebelum ditetapkan menjadi tersangka, tidak diperlukan persetujuan presiden.

Sementara istilah "tindakan kepolisian" tidak dijelaskan di dalam UU BPK dan UU

Pasal 25 ayat (2) UU BPK.

39 Pasal 1 Angka 20 Undang-Undang Nomor 8 Tahun 1981 tentang Hukum Acara Pidana.

$40 \quad$ Pasal 1 angka 21 Undang-Undang Nomor 8 Tahun 1981 tentang Hukum Acara Pidana.
MK. Namun pengertian tindakan kepolisian bisa didapatkan dalam UU Nomor 13 Tahun 1970 tentang Tata Cara Tindakan Kepolisian terhadap Anggota-Anggota/Pimpinan Majelis Permusyawaratan Rakyat Sementara dan Dewan Perwakilan Rakyat Gotong-Royong. Di dalam UU tersebut, tindakan kepolisian adalah: a. pemanggilan sehubungan dengan tindak pidana;

b. meminta keterangan tentang tindak pidana;

c. penangkapan;

d. penahanan;

e. penggeledahan; dan

f. penyitaan. ${ }^{41}$

Di dalam KUHAP, terdapat Bab $\mathrm{V}$ yang mengatur mengenai penangkapan, penahanan, penggeledahan badan, pemasukan rumah, penyitaan dan pemeriksaan surat, namun pada Bab VIII tentang Berita Acara, beberapa tindakan yang disebutkan dibuatkan berita acara adalah: a. pemeriksaan tersangka; b. penangkapan; c. penahanan; d. penggeledahan; e. pemasukan rumah; f. penyitaan benda; g. pemeriksaan surat; h. pemeriksaan saksi; 1 . pemeriksaan di tempat kejadian; j. pelaksanaan penetapan dan putusan pengadilan; dan $\mathrm{k}$. pelaksanaan tindakan lain sesuai dengan ketentuan dalam undang-undang ini.

Kategori berdasarkan tahapan adalah tahapan penyelidikan, penyidikan, penuntutan, pemeriksaan di sidang pengadilan, dan pelaksanaan putusan pengadilan. Artinya, untuk hakim konstitusi dan anggota BPK, persetujuan presiden tidak terbatas pada saat penangkapan dan penahanan atau pada tahap penyidikan, namun lebih luas daripada itu. Pada saat pemanggilan sehubungan dengan tindak pidana dan meminta keterangan tentang tindak pidana sudah diperlukan adanya persetujuan presiden. Apabila mengacu pada pengertian tindakan kepolisian, maka untuk memanggil, meminta keterangan, menangkap, menahan,

$41 \quad$ Pasal 1 Angka 1 Undang-Undang Nomor 13 Tahun 1970 tentang Tata Cara Tindakan Kepolisian terhadap Anggota-Anggota/Pimpinan Majelis Permusyawaratan Rakyat Sementara dan Dewan Perwakilan Rakyat Gotong-Royong. 
menggeledah, dan menyita-pun diperlukan persetujuan presiden. Ketentuan ini berbeda dengan hakim agung.

Frasa "pemanggilan dan permintaan keterangan kepada anggota DPR yang diduga melakukan tindak pidana" yang diberlakukan pada anggota DPR dapat dikatakan menjadi multitafsir. Apabila dilihat dari kategori tindakan maka yang memerlukan persetujuan tertulis presiden adalah tindakan pemanggilan dan permintaan keterangan, sedangkan dari kategori status, kata "diduga" dapat disamakan dengan "disangka" sehingga dapat ditafsirkan pada saat status yang bersangkutan menjadi tersangka. Berdasarkan hal tersebut, pemanggilan dan permintaan keterangan anggota DPR dalam status sebagai tersangka pada tahap penyidikan, bukan sebagai saksi pada tahap penyelidikan.

Rumusan untuk anggota DPR tidak dapat disamakan dengan yang diberlakukan untuk hakim konstitusi dan anggota BPK, karena secara a contrario dapat ditafsirkan, di luar "pemanggilan dan permintaan keterangan sehubungan dengan terjadinya tindak pidana" tidak diperlukan persetujuan presiden. Apabila menggunakan bahasa lugas, untuk memanggil dan meminta keterangan anggota DPR sebagai tersangka diperlukan persetujuan presiden, namun di luar itu tidak memerlukan persetujuan presiden. Tindakan di luar pemanggilan dan permintaan keterangan adalah penangkapan, penahanan, penggeledahan, pemasukan rumah, dan penyitaan.

Inkonsistensi secara teknis, untuk anggota DPR disebutkan persetujuan "tertulis" presiden, sedangkan untuk hakim agung, hakim konstitusi, dan anggota BPK tidak ada kata "tertulis". Apabila menggunakan analisis dari aspek bahasa, dapat diartikan jika tidak ada kata "tertulis" maka persetujuan dapat diberikan secara lisan.

Persetujuan dalam konteks ini dapat disamakan dengan izin. Izin adalah keputusan pejabat pemerintahan yang berwenang sebagai wujud persetujuan atas permohonan warga masyarakat sesuai dengan ketentuan peraturan perundang-undangan. ${ }^{42}$ Menurut Sjachran Basah, izin adalah perbuatan hukum administrasi negara bersegi satu yang menghasilkan peraturan dalam hal kontrol berdasarkan persyaratan dan prosedur sebagaimana ditetapkan oleh peraturan perundang-undangan yang berlaku. ${ }^{43}$ Izin adalah suatu persetujuan dari penguasa berdasarkan peraturan perundang-undangan dan peraturan pemerintah. ${ }^{44}$ Melalui sistem perizinan diharapkan dapat tercapainya tujuan tertentu di antaranya: ${ }^{45}$

a. adanya suatu kepastian hukum;

b. perlindungan kepentingan umum;

c. pencegahan kerusakan atau pencemaran lingkungan;

d. pemerataan distribusi tertentu

Di dalam undang-undang administrasi pemerintahan ${ }^{46}$, keputusan badan dan/atau pejabat pemerintahan berbentuk izin apabila:

a. diterbitkan persetujuan sebelum kegiatan dilaksanakan; dan

b. kegiatan yang akan dilaksanakan merupakan kegiatan yang memerlukan perhatian khusus dan/atau memenuhi ketentuan peraturan perundang-undangan. Izin, dispensasi, atau konsesi yang diajukan oleh pemohon wajib diberikan persetujuan atau penolakan oleh badan dan/atau pejabat pemerintahan paling lama 10 (sepuluh) hari kerja sejak diterimanya permohonan, kecuali ditentukan lain dalam ketentuan peraturan perundang-undangan. Ketentuan mengenai jumlah hari untuk pemberian persetujuan presiden perlu disinkronkan dengan ketentuan hari mengenai pemberian izin sebagaimana diatur dalam undang-undang administrasi pemerintahan ini.

\section{Pengecualian}

Ketentuan pengecualian perlunya persetujuan presiden juga terdapat

42 Pasal 1 angka 19 Undang-Undang Nomor 30 Tahun 2014 tentang Administrasi Pemerintahan

43 Nomensen Sinamo, Hukum Administrasi Negara, Suatu Kajian Kritis tentang Birokrasi Negara, Jakarta: Permata Aksara, 2016, hal. 88.

$44 \quad$ Ibid., hal. 89.

45 Ibid., hal. 90.

46 Pasal 39 ayat (2) dan ayat (5) Undang-Undang Nomor 30 Tahun 2014 tentang Administrasi Pemerintahan. 
ketidaksinkronan dan inkonsistensi, sebagai berikut.

g. Pengecualian untuk hakim agung diberlakukan apabila hakim agung tertangkap tangan melakukan tindak pidana kejahatan; atau berdasarkan bukti permulaan yang cukup, disangka telah melakukan tindak pidana kejahatan yang diancam dengan pidana mati, atau tindak pidana kejahatan terhadap keamanan negara. ${ }^{47}$

h. Pengecualian untuk hakim konstitusi diberlakukan apabila hakim konstitusi tertangkap tangan melakukan tindak pidana; atau berdasarkan bukti permulaan yang cukup disangka telah melakukan tindak pidana kejahatan yang diancam dengan pidana mati atau tindak pidana kejahatan terhadap keamanan negara. ${ }^{48}$

i. Pengecualian untuk anggota BPK diberlakukan apabila anggota BPK tertangkap tangan melakukan tindak pidana kejahatan, atau berdasarkan bukti permulaan yang cukup, disangka telah melakukan tindak pidana kejahatan yang diancam dengan pidana mati, atau tindak pidana kejahatan terhadap keamanan negara. ${ }^{49}$

j. Pengecualian untuk anggota DPR diberlakukan apabila anggota DPR tertangkap tangan melakukan tindak pidana; disangka melakukan tindak pidana kejahatan yang diancam dengan pidana mati atau pidana penjara seumur hidup atau tindak pidana kejahatan terhadap kemanusiaan dan keamanan negara berdasarkan bukti permulaan yang cukup; atau disangka melakukan tindak pidana khusus. (antara lain meliputi tindak pidana korupsi, tindak pidana terorisme, pelanggaran HAM berat, tindak pidana perdagangan orang, tindak pidana penyalahgunaan narkotika). ${ }^{50}$

\footnotetext{
$47 \quad$ Pasal 17 ayat (1) UU MA.

$48 \quad$ Pasal 6 ayat (2) UU MK.

49 Pasal 25 ayat (1) UU BPK.

$50 \quad$ Pasal 245 ayat (2) UU MD3.
}

Pelaksanaan penangkapan atau penahanan hakim agung dalam kondisi pengecualian tersebut, selambat-lambatnya dalam waktu 2 (dua) kali 24 (dua puluh empat) jam harus dilaporkan kepada Jaksa Agung. ${ }^{51}$ Ketentuan untuk anggota BPK dalam waktu 1x24 (satu kali dua puluh empat) jam harus dilaporkan kepada Jaksa Agung yang berkewajiban untuk memberitahukan penahanan tersebut kepada presiden, DPR, dan BPK. ${ }^{52}$ Inkonsistensi atau ketidaksinkronan dalam hal pengecualian terdapat pada jenis tindak pidana yang dikecualikan dan jangka waktu pelaporan setelah tangkap tangan, serta kepada siapa laporan atau pemberitahuan tersebut disampaikan.

\section{Pelaku Penegakan Hukum}

Pada ketentuan khusus dalam proses pidana terhadap hakim agung, hakim konstitusi, dan anggota BPK terdapat rumusan "atas perintah jaksa agung”, namun terhadap anggota DPR, tidak disebutkan ada atas perintah jaksa agung. Marwan Effendy ${ }^{53}$ menyatakan, dalam lintasan sejarah, setelah digantinya Herzien Inlandsch Reglement (HIR) dengan KUHAP, wewenang kejaksaan di dalam penegakan hukum terkait dengan penyidikan sebagaimana diatur dalam Pasal 39 HIR hampir seluruhnya dicabut, bahkan dengan keluarnya Undang-Undang Nomor 30 Tahun 2002 tentang Komisi Pemberantasan Tindak Pidana Korupsi, wewenang di bidang penuntutan bukan lagi monopoli kejaksaan.

Pengaturan yang demikian akan berimplikasi terhadap eksistensi Kejaksaan Republik Indonesia dalam penegakan hukum. Hal ini berarti aparat penegak hukum yang berwenang melakukan penyidikan tidak hanya kejaksaan, sehingga selain "atas perintah Jaksa Agung" juga dimungkinkan atas perintah atasan penyidik yang lain, seperti Pimpinan KPK.

UU KPK ternyata mengatur mengenai ketentuan khusus, yaitu dalam hal seseorang ditetapkan sebagai tersangka oleh KPK,

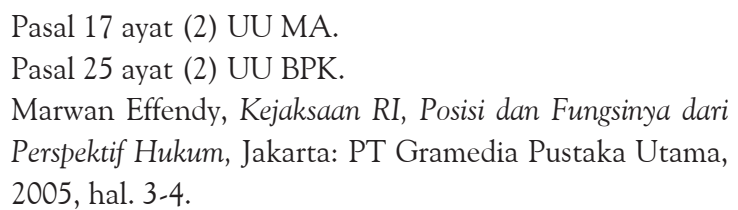


terhitung sejak tanggal penetapan tersebut, prosedur khusus yang berlaku dalam rangka pemeriksaan tersangka yang diatur dalam peraturan perundang-undangan lain, tidak berlaku berdasarkan undang-undang ini. ${ }^{54}$ Penjelasan pasal tersebut menyebutkan yang dimaksud dengan "prosedur khusus" adalah kewajiban memperoleh izin bagi tersangka pejabat negara tertentu untuk dapat dilakukan pemeriksaan.

Paling tidak terdapat 6 (enam) permasalahan konsistensi dan sinkronisasi pengaturan mengenai ketentuan khusus terhadap pejabat pemerintahan dalam proses pidana. Pertama, tidak semua undang-undang yang mengatur mengenai lembaga negara utama mengatur ketentuan khusus terhadap pejabat negara utama dalam proses pidana. Pejabat negara utama yang tidak diatur adalah anggota MPR dan anggota DPD karena tidak diatur dalam UU MD3 dan presiden karena tidak ada undang-undang khusus yang mengatur lembaga kepresidenan dan diasumsikan telah diatur dalam UUD 1945, meskipun hal tersebut akan menimbulkan multiinterpretasi.

Kedua, tidak ada konsistensi dan sinkronisasi dalam konteks apa presiden memberikan persetujuan. Apakah dalam kategori tindakan, yaitu pemeriksaan, penangkapan dan penahanan; atau status, sebagai saksi atau tersangka; atau tahapan, penyelidikan atau penyidikan. Ketiga, tindak pidana yang dikecualikan juga tidak sinkron, untuk anggota DPR lebih luas dibandingkan hakim agung, hakim konstitusi, dan anggota BPK.

Keempat, lembaga yang melakukan penegakan hukum, untuk hakim agung, hakim konstitusi, dan anggota BPK adalah jaksa agung, sementara untuk anggota DPR tidak dieksplisitkan. Kelima, tindak lanjut setelah tangkap tangan untuk hakim konstitusi dan anggota DPR tidak ada ketentuan bahwa setelah tangkap tangan harus ada laporan oleh jaksa agung. Ketentuan untuk hakim agung dan

$54 \quad$ Pasal 46 ayat (1) Undang-Undang Nomor 30 tahun 2002 tentang Komisi Pemberantasan Tindak Pidana Korupsi. anggota BPK berbeda jangka waktu dan kepada siapa laporan tersebut disampaikan. Keenam, ketentuan khusus tersebut ternyata tidak berlaku bagi KPK karena UU KPK mengeliminir perlunya izin presiden. Hal ini berarti terdapat ketidaksinkronan antarpenegak hukum, sebab apabila tindak pidana korupsi tersebut disidik oleh kejaksaan, masih berlaku ketentuan mengenai izin presiden (kecuali untuk anggota DPR karena ada pengecualian tindak pidana khusus yang termasuk korupsi).

\section{Penutup}

Sulit untuk menemukan esensi dari persetujuan presiden dalam proses pidana terhadap anggota DPR, hakim agung, hakim konstitusi, dan anggota BPK. Esensi persetujuan presiden dalam proses pidana terhadap beberapa pejabat yang termuat dalam pendapat MK pada putusan uji materi undang-undang, seperti: untuk sekedar mengetahui adanya pejabat yang sedang menjalani proses hukum, untuk perlindungan hukum dalam pelaksanaan tugas konstitusional, untuk mekanisme checks and balances, dan agar tidak diperlakukan secara sewenang-wenang dan sembrono, memiliki kelemahan dan kurang mempunyai argumentasi yang kuat. Esensi persetujuan presiden berdasarkan sejarah undang-undang yang mengatur mengenai hukum acara pidana khusus dan tata cara tindakan kepolisian hanya ditemukan untuk anggota legislatif dan terkait dengan hak imunitas. Bagaimana ketentuan hukum acara pidana khusus selain untuk anggota legislatif tidak ada atau tidak diketahui secara pasti. Analisis esensi persetujuan presiden dalam proses pidana dengan mencari rujukan pada kekuasaan dan hak presiden yang diatur UUD 1945 juga tidak menemukan rujukan yang jelas. Salah satu kemungkinan esensi persetujuan presiden dalam proses pidana pejabat negara utama adalah untuk mengetahui adanya pejabat negara yang sedang menjalani proses hukum sehingga roda pemerintahan berpotensi terganggu. Berdasarkan esensi ini tidak tepat apabila solusinya dengan memberikan kewenangan 
presiden untuk memberikan persetujuan atau tidak memberikan persetujuan terhadap proses pidana yang sedang dijalani oleh pejabat negara utama.

Pengaturan mengenai proses pidana terhadap pejabat pemerintahan terdapat ketidaksinkronan dan inkonsistensi. Secara garis besar ketidaksinkronan tersebut dapat dilihat dari istilah dan tahapan; pengecualian; dan pelaku penegakan hukum. Secara lebih rinci terdapat 6 (enam) ketidaksinkronan. Pertama, tidak semua undang-undang yang mengatur mengenai lembaga negara merumuskan ketentuan khusus terhadap pejabat negara dalam proses pidana. Kedua, terdapat perbedaan pada kategori tindakan, status, atau tahapan apa presiden memberikan persetujuan. Ketiga, tindak pidana yang dikecualikan untuk anggota DPR lebih luas dibandingkan untuk hakim agung, hakim konstitusi, dan anggota BPK. Keempat, lembaga yang melakukan penegakan hukum untuk hakim agung, hakim konstitusi, dan anggota BPK adalah jaksa agung, sementara untuk anggota DPR tidak dieksplisitkan. Kelima, tindak lanjut setelah tangkap tangan untuk hakim konstitusi dan anggota DPR tidak ada ketentuan harus ada laporan oleh jaksa agung, sementara untuk hakim agung dan anggota BPK berbeda jangka waktu dan kepada siapa laporan tersebut disampaikan. Keenam, ketentuan khusus tersebut ternyata tidak berlaku bagi KPK karena UU KPK mengeliminir perlunya izin presiden.

Sebagai saran dan rekomendasi, ada tiga opsi yang dapat dipilih terhadap esensi persetujuan presiden dan agar terdapat konsistensi pengaturan. Pertama meniadakan aturan mengenai persetujuan presiden tersebut dan perlu dikaji opsi untuk menghidupkan kembali forum previligiatum atau peradilan dengan mekanisme khusus bagi pejabat negara utama. Kedua, mengatur dalam undang-undang tersendiri mengenai proses hukum terhadap pejabat negara utama. Ketiga, ketentuan proses pidana terhadap pejabat negara utama dimasukkan dalam bagian undang-undang yang mengatur mengenai hukum acara pidana.

\section{Daftar Pustaka}

\section{Jurnal dan Hasil Penelitian}

Chandranegara, Ibnu Sina. "Penuangan Checks and Balances ke dalam Konstitusi". Jurnal Konstitusi. Vol. 13. No. 3. September 2016.

Habibi, Nur. "Politieke Beslissing dalam Pemakzulan Presiden Republik Indonesia”. Jurnal Cita Hukum. Vol. 3. No. 2. Desember 2015.

Hantoro, Novianto M. "Klasifikasi Jabatan dalam Kelembagaan Negara: Permasalahan Kategori Pejabat Negara". Jurnal Negara Hukum. Vol. 7. No. 2. November 2016.

Mulyani, Tri. "Izin Presiden untuk Melakukan Pemeriksaan terhadap Kepala Daerah yang Diduga Melakukan Tindak Pidana Korupsi”. Tesis. Program Pasca-Sarjana Universitas Kristen Satya Wacana. Salatiga. 2010.

Rantung, Bobby. "Kewenangan Presiden Dalam Memberikan Grasi Kepada Terpidana Mati Kasus Narkoba”. Lex Privatum. Vol. 4. No. 4. April 2016.

Saragih, Try Sarmedi. "Kewenangan Penyidik dalam Memanggil dan Memeriksa Anggota Dewan Perwakilan Rakyat yang Diduga Melakukan Tindak Pidana”, diakses secara online dari http://e-journal.uajy. ac.id/11226/1/JURNAL.pdf pada 1 Agustus 2018. à diberi vol dan no jurnal

Susilowati, W.M Hery. "Sistem Pemerintahan Indonesia Menurut UUD 1945 (Suatu Kajian Teoritis)". Jurnal Perspektif. Vol. 9. No. 3. Ed. Juli 2003.

Yudanto, Dika dan Nourma Dewi. "Sinkronisasi Undang-Undang Administrasi Pemerintahan dengan Undang-Undang Tindak Pidana Korupsi dalam Penyelesaian Kasus Penyalahgunaan Wewenang Pejabat Pemerintah di Indonesia". Jurnal Serambi Hukum. Vol. 10. No. 02. Agustus 2016 . Januari 2017. 


\section{Buku}

Akbar, Patrialis. Lembaga-Lembaga Negara Menurut UUD NRI Tahun 1945. Jakarta: Sinar Grafika. 2013.

Asshiddiqie, Jimly. Perkembangan dan Konsolidasi Lembaga Negara Pasca-Reformasi. Jakarta: Sekretariat Jenderal dan Kepaniteraan Mahkamah Konstitusi. 2006.

Bahri, Zainul. Kamus Hukum. Bandung: Angkasa. 1994.

Effendy, Marwan. Kejaksaan RI, Posisi dan Fungsinya dari Perspektif Hukum. Jakarta: PT Gramedia Pustaka Utama. 2005.

Sinamo, Nomensen. Hukum Administrasi Negara, Suatu Kajian Kritis tentang Birokrasi Negara. Jakarta: Permata Aksara. 2016.

Martosoewignjo, Sri Soemantri. Hukum Tata Negara Indonesia, Pemikiran dan Pandangan. Cetakan kedua. Bandung: PT. Remaja Rosdakarya. 2015.

Indrati, Maria Farida. et.all. Laporan Kompendium Bidang Hukum PerundangUndangan. Jakarta: Departemen Hukum dan HAM RI. 2008.

Fadjar, Abdul Mukhtie. Sejarah, Elemen dan Tipe Negara Hukum. Malang: Setara Press. 2016.

\section{Putusan Pengadilan}

Putusan Mahkamah Konstitusi Nomor 73/PUUIX/2011 dalam perkara pengujian UndangUndang Nomor 32 Tahun 2004 tentang Pemerintahan Daerah sebagaimana telah diubah terakhir dengan Undang-Undang Nomor 12 Tahun 2008 tentang Perubahan Kedua Atas Undang-Undang Nomor 32 Tahun 2004 tentang Pemerintahan Daerah.
Putusan Mahkamah Konstitusi Nomor 76/ PUU-XII/2014 dalam perkara pengujian Undang-Undang Nomor 17 Tahun 2014 tentang Majelis Permusyawaratan Rakyat, Dewan Perwakilan Rakyat, Dewan Perwakilan Daerah, dan Dewan Perwakilan Rakyat Daerah.

Putusan Mahkamah Konstitusi Nomor 125/ PUU-XIII/2015 dalam perkara pengujian Undang-Undang Nomor 22 Tahun 2004 tentang Komisi Yudisial sebagaimana telah diubah dengan Undang-Undang Nomor 18 Tahun 2011 tentang Perubahan Atas Undang-Undang Nomor 22 Tahun 2004 tentang Komisi Yudisial dan UndangUndang Nomor 14 Tahun 1985 tentang Mahkamah Agung sebagaimana telah diubah terakhir dengan Undang-Undang Nomor 3 Tahun 2009 tentang Perubahan Kedua Atas Undang-Undang Nomor 14 Tahun 1985 tentang Mahkamah Agung.

Putusan Mahkamah Konstitusi Nomor 16/PUUXVI/2018 dalam perkara pengujian UndangUndang Nomor 2 Tahun 2018 tentang Perubahan Kedua atas Undang-Undang Nomor 17 Tahun 2014 tentang Majelis Permusyawaratan Rakyat, Dewan Perwakilan Rakyat, Dewan Perwakilan Daerah, dan Dewan Perwakilan Rakyat Daerah. 